\title{
Addition of Tofu Waste to Concentrate Feed on Ruminant Animal Value
}

\author{
Engkus Ainul Yakin ${ }^{1}$, Sri Sukaryani ${ }^{1}$, Catur Suci Purwati ${ }^{1}$ and Desi Lestari ${ }^{1}$ \\ Animal Husbandry, Agriculture Faculty, Universitas Veteran Bangun Nusantara \\ J1. Letjen Sujono Humardani No. 1, Sukoharjo 57521, Central Java, Indonesia \\ Corresponding author : engkus_ainul@yahoo.com
}

\begin{abstract}
The purpose of this study was to determine the effect of the addition of tofu waste in concentrate feed on the nutritional value of ruminant animal feed. Concentrate feed used in this study uses concentrated feed for sheep. Tofu waste was obtained from the place of making tofu in Girimarto sub-district, Wonogiri Regency. The research method used was concentrate feed for sheep given the addition of tofu waste. The study used 3 treatments namely $\mathrm{T} 0=$ Concentrate without the addition of tofu waste (control), $\mathrm{T} 1=$ Concentrate with $10 \%$ tofu waste addition, and T2 $=$ Concentrate with $20 \%$ tofu waste addition. The results of the study were analyzed in the laboratory to determine the nutritional value of sheep feed. The study was designed with a completely randomized design. Observation parameters of nutritional value of feed include dry matter, crude protein, crude fiber and in vitro digestibility. The results showed that dry matter content was $78.54 \pm 0.23 \%$ and crude protein was $16.63 \pm 0.46 \%$ with the addition of tofu waste until $20 \%$ showed a significant difference, whereas crude fiber was $20.37 \pm 0.48 \%$ showed no significant difference, while the dry matter digestibility and organic matter digestibility showed no significant difference. The conclusion of this study was the addition of tofu waste in the concentrate had an effect on the dry matter and crude protein, but not significantly different on crude fiber. The addition of tofu waste to the concentrate did not affect the digestibility of dry matter or the digestibility of organic matter.
\end{abstract}

Key words : Animal feed, concentrate, in vitro digestibility, tofu waste

\section{Introduction}

Feed is one of the largest components of all costs incurred in the livestock business. Costs incurred for livestock confiscate production costs around 60-80\% (Santoso, 1986). Even though corn is mostly produced domestically, in fact it has to compete with humans, even in some regions it is made a staple food. Fish meal $95 \%$ still has to be imported, so the price in the country is very expensive as is the case with soybean meal which is currently still mostly imported (Santoso, 1986).

To meet market demand and increase livestock productivity, efforts should be made to find alternative feed sources, namely by replacing some of these ingredients with other ingredients that are cheaper, easier to obtain, and highly nutritious. One alternative that can be used is to utilize solid waste from tofu. 
Tofu industry is one industry that has a rapid development. There are 84 thousand units of tofu industry in Indonesia with a production capacity reaching 2.56 million tons per year (Sadzali, 2010). The amount of tofu waste formed is in the range of 25-35\% of the produced tofu product. Tofu waste can be used as a food source of protein because it contains high enough crude protein ranging from 23-29\% (Mathius et al., 2001) and other nutrient content is $4.93 \%$ fat (Nuraini, 2009) and crude fiber $22.65 \%$ (Duldjaman, 2004).

In general, this abundant waste can be used directly as animal feed but low amino acids and high crude fiber are usually a limiting factor in its use as feed. The use of high crude fiber, in addition to reducing digestible components also causes a decrease in the activity of enzymes that break down food substances, such as enzymes that help digest carbohydrates, proteins and fats (Parakkasi, 1991)

Tofu waste is a product of food industry waste that can still be optimally utilized as an alternative to animal feed ingredients (Tetty, 2006 ). Tofu waste is suitable as animal feed because it is a source of vegetable protein in animal feed, it is estimated that fresh tofu waste has a water content of $70-80 \%$. The dry weight of tofu pulp contains 23.6 $24 \%$ protein and $12 \%$ crude fiber (Witjaksono, 2005). Besides protein and crude fiber, tofu waste also still contains $5.9 \%$ fat, $67.5 \%$ carbohydrate, $19 \%$ calcium and $29 \%$ phosphorus (Suprapti, 2005).

Tofu waste can be used as a substitute for coconut cake which is commonly used to prepare rations. Coconut cake has $18.6 \%$ protein content, $15 \%$ crude fiber, $0.18 \%$ calcium and $0.56 \%$ phosphorus. When compared with tofu pulp, the nutritional elements contained in coconut cake are lower and the price is also more expensive.

Based on the description above, it is important to conduct research on tofu waste in order to determine the effect of the use of tofu solid waste in concentrate feed on the nutritional value of ruminant animal feed.

\section{Materials and Methods}

\section{Experimental design}

Tofu waste that has been obtained is added to the sheep concentrate feed. The addition of tofu dregs in sheep concentrate feed used four treatments with three replications namely $\mathrm{T} 1=$ concentrate without the addition of tofu waste (control), $\mathrm{T} 2=$ concentrate with the addition of $10 \%$ tofu waste, and $\mathrm{T} 2=$ concentrate with the addition of $20 \%$ tofu waste.

\section{Variable}

\section{Dry matter}

If the feed material is heated at a temperature of $105^{\circ} \mathrm{C}$ for 5 hours or at $135^{\circ} \mathrm{C}$ for 2 hours, a non-aqueous material will be obtained. This material is called dry matter. Evaporated water is the water content of feed ingredients whose amounts can be calculated by the following formula:

$\mathrm{H}=(\mathrm{WB}-\mathrm{WA}) / \mathrm{WB} \times 100$

$\mathrm{H}=$ Water contained in feed ingredients

$\mathrm{WB}=$ Initial weight of analyzed feed ingredients (grams)

$\mathrm{WA}=$ Weight of feed ingredients after heating (grams) 


\section{Crude protein}

Samples were analyzed with the Kjeldahl tool, which is a method of detecting nitrogen by the titration treatment of sodium hydroxide $(\mathrm{NaOH})$. The protein content of feed ingredients is calculated by the following formula:

$\mathrm{P}=(100 \times(3.5 \times 6.25 \times(\mathrm{TS}-\mathrm{TK})) / \mathrm{BS} \times 100$

$\mathrm{P}=$ Protein contained in feed ingredients $(\%)$

$\mathrm{TS}=$ titration results in samples (millimeters)

$\mathrm{TK}=$ titration results in controls (millimeters)

$\mathrm{BS}=$ Weight of sample used (milligrams)

\section{Crude fiber}

Calculated by calculating the percentage of material lost after the feed material was burned at $7000 \mathrm{C}$ for 1 hour or done by adding concentrated $\mathrm{H} 2 \mathrm{SO} 4$ solution while heating for half an hour, then cooled for half an hour with the addition of $\mathrm{NaOH}$.

\section{In vitro digestibility}

In vitro digestibility measurements carried out refer to the procedure (Tilley and Terry, 1963) which has been modified by (Utomo, 2010), where there are two differences, namely in the stage I procedure to stage II without any residual washing process, so the addition of $\mathrm{HCl}$ and pepsin is immediately carried out. In addition, the material modification procedure used is only half of the Tilley and Terry procedure (1963), so that the samples and reagents used are only half, the capacity of the test tube used was also half that of the $50 \mathrm{ml}$ volume test tube.

Sample preparation. The sample used was weighed as much as $0.25 \mathrm{~g}$ using analytical scales, then put into a $50 \mathrm{ml}$ test tube and incubated in a water bath at $39^{\circ} \mathrm{C}$ overnight so that the temperature was the same as in the rumen.

Intake of rumen fluid. The tools used to extract rumen fluid from fistula cows are aspirators and syringes. Thermos were previously filled with warm water (temperature $39^{\circ} \mathrm{C}$ ) until full, then discarded before being filled with rumen fluid. Rumen fluid is taken using an aspirator, then put in a thermos until it is full to prevent oxygen. The rumen fluid is then filtered using a four-layer gauze cloth and put into an erlenmeyer while flowing with $\mathrm{CO}_{2}$ gas and incubated at $39^{\circ} \mathrm{C}$. Then add $\mathrm{McDougal}$ solution or artificial saliva as much as $1600 \mathrm{ml}$

Digestion measurement. The first stage, after one night, a tube containing a sample and a mixture of rumen fluid with McDougal solution in the ratio of 1 rumen fluid $(5 \mathrm{ml})$ : $4 \mathrm{McDougal}$ solution $(20 \mathrm{ml})$, incubated in a water bath at $39^{\circ} \mathrm{C}$ for 48 hours. Samples were also prepared for the calculation of VFA and microbial protein. The second step in the second 48 hours added $20 \% \mathrm{HCl}$ to each test tube $3 \mathrm{ml}$ in stages $(0.5 ; 0.5 ; 1 ; 1 \mathrm{ml})$ and after that $1 \%$ pepsin was added as much as $1 \mathrm{ml}$. For every one incubation point from the treatment, blank and standard incubated were replicated three times. Blank is a tube that is filled without treatment sample treatment, its function as a correction factor. Standard is a tube filled with CBC. Shaking out is done manually every 8 hours. Furthermore, the residue left in the tube is filtered with a crucible that has been filled with glass wool that is known to have a constant weight. Then the residue with glass wool is heated in an oven at $105^{\circ} \mathrm{C}$ for 24 hours and weighed and resumed with the ashing process (Utomo, 2010) 
Calculation:

A: Weight of initial sample (air dried)

$\mathrm{B}: \%$ dry matter

$\mathrm{C}: \%$ organic matter

D: The weight of the crucible is empty

E: Crucible weight + residue

F: Crucible + ash weight

G: Initial dry matter, $g=(A X ~ B) / 100$

$\mathrm{H}$ : Remaining BK (sample), $\mathrm{g}=\mathrm{E}-\mathrm{D}$

$\mathrm{I}$ : BK remaining (blank) $\mathrm{g}=\mathrm{E}-\mathrm{D}$

A: Initial BO, $g=(G X$ C $) / 100$

$\mathrm{K}$ : $\mathrm{BO}$ remainder (sample), $\mathrm{g}=\mathrm{E}-\mathrm{F}$

$\mathrm{L}$ : $\mathrm{BO}$ remainder (blank), $\mathrm{g}=\mathrm{E}-\mathrm{F}$

$\%$ dry matter digestibility $=(\mathrm{G}-(\mathrm{H}-\mathrm{I})) / \mathrm{G} \times 100$

$\%$ digestibility of organic matter $=(\mathrm{J}-(\mathrm{K}-\mathrm{L})) / \mathrm{J}$ x $100($ Harris, 1970) .

\section{Statistic analysis}

Data were analyzed using Analysis of Variance (ANOVA) unidirectional pattern and followed by Duncan's Multiple Range Test (DMRT) (Astuti, 2007) if there were differences.

\section{Results and Discussion}

\section{Chemical Composition}

Data on average chemical composition including dry matter, crude protein, crude fat, crude fiber and ash, from the study are listed in Table 1.

Table 1. Average chemical composition of research (\%)

\begin{tabular}{lrrr}
\hline \hline \multirow{2}{*}{ Proksimat (\%) } & \multicolumn{3}{c}{ Treatment } \\
\cline { 2 - 4 } & $\mathrm{T} 1$ & $\mathrm{~T} 2$ & $\mathrm{~T} 3$ \\
\hline & & \\
Dry matter & $86,08^{\mathrm{b}} \pm 0,19$ & $80,17^{\mathrm{b}} \pm 0,14$ & $78,54^{\mathrm{a}} \pm 0,23$ \\
Crude protein & $12,73^{\mathrm{a}} \pm 0,17$ & $15,73^{\mathrm{b}} \pm 0,27$ & $16,63^{\mathrm{c}} \pm 0,46$ \\
Crude fiber $^{\mathrm{ns}}$ & $21,05 \pm 0,28$ & $20,36 \pm 0,55$ & $20,37 \pm 0,48$ \\
\hline a,b,c Superscript on the same rows shows significant $(\mathrm{P}<0,05)$ & \\
ns=not significant & & \\
T1= Concentrat without tofu waste substitution & & \\
T2= Concentrat with 10\% tofu waste substitution & \\
T3= Concentrat with 20\% tofu waste substitution
\end{tabular}

\section{Dry matter}

The average proximate dry matter (BK) results are listed in Table 1. All treatments showed significantly different results. In treatment $\mathrm{T} 1$ where the concentrate without the addition of tofu dregs is high DM value because the content of the concentrate material is around $86.08 \%$, while $\mathrm{T} 2$ is the concentrate with the addition of tofu dregs of $10 \%$ 
showing dry matter at $80.17 \%$. The decrease in dry matter content is caused when mixing occurs with tofu waste which has a high enough water content so that the dry matter content in $\mathrm{T} 2$ becomes down. $\mathrm{T} 3$ shows dry matter content of $78.54 \%$. The T3 content shows the lowest dry matter content among the three treatments. This is due to the addition of tofu pulp by $20 \%$, causing the greatest decrease in dry matter content.

\section{Crude protein}

The results of the average crude protein $(\mathrm{CP})$ chemical composition are listed in table 1. The results of the test of the addition of tofu pulp to the concentrate have a very significant effect $(\mathrm{P}<0.01)$ on the crude protein $(\mathrm{CP})$ chemical composition of all treatments.

The $\mathrm{T} 1$ treatment showed a crude protein content of $12.66 \%$. The $\mathrm{CP}$ concentrate content is around $12-14 \%$. Crude protein content in $\mathrm{t} 2$ is $15.58 \%$. This increase in CP content is due to the addition of tofu pulp by $10 \%$ affecting the concentration of $\mathrm{CP}$ content. The content of CP pulp know around 23-29\% when mixing occurs it will increase the concentration of CP concentrate. In T3, it showed a CP content of $16.44 \%$ indicating the highest increase in $\mathrm{CP}$ content of the three treatments. This happens because the addition of tofu waste by $20 \%$ will increase the $\mathrm{CP}$ content in the concentrate.

\section{Crude Fiber}

The mean results of the chemical composition of crude fiber (CF) are listed in Table 1. The results of the mean test for the addition of tofu dregs to the concentrate did not different significantly between all treatments for crude fiber (CF).

The results of the average crude fiber content of the three successive treatments are T1 $=20.99 \% ; \mathrm{T} 2=20.63 \%$ and $\mathrm{T} 3=21.88 \%$ showed no significant difference. The crude fiber content that is not significantly different between treatments occurs because the concentrate is a feed that has a relatively low crude fiber content, while tofu waste also has a low crude fiber content so that when mixed with crude fiber content also shows the same results.

\section{In Vitro Digestibility}

Data on average Dry Matter (DM) digestibility and Organic Matter (OM) digestibility of the three treatments during the study are listed in Table 2.

Table 2. Average Dry matter and Organic matter Digestibility (\%)

\begin{tabular}{lccc}
\hline \multirow{2}{*}{ Proksimat (\%) } & \multicolumn{3}{c}{ Treatment } \\
\cline { 2 - 4 } & T1 & T2 & T3 \\
$\begin{array}{l}\text { Dry matter (DM) } \\
\text { digestibility }\end{array}$ & $55,30 \pm 0,37$ & $54,86 \pm 0,65$ & $55,67 \pm 0,58$ \\
$\begin{array}{l}\text { Organic matter }(\mathrm{OM}) \\
\text { digestibility }\end{array}$ & $54,97 \pm 0,63$ & $55,11 \pm 0,80$ & $55,67 \pm 0,45$ \\
\hline ns=not significant & & \\
$\begin{array}{l}\text { T1= Concentrat without tofu waste substitution } \\
\text { T2= Concentrat with 10\% tofu waste substitution }\end{array}$ & \\
T3= Concentrat with 20\% tofu waste substitution
\end{tabular}


The DM digestibility mean results are listed in Table 2 . The three mean treatments were $\mathrm{T} 1=54.96 \%, \mathrm{~T} 2=54.94 \%$, and $\mathrm{T} 3=55.31 \%$. Statistical analysis using DMRT showed no significant difference.

The mean OM digestibility results are listed in Table 2 . The three mean treatments were $\mathrm{T} 1=54.68 \%, \mathrm{~T} 2=55.08 \%$, and $\mathrm{T} 3=55.08 \%$. Statistical analysis using DMRT shows the results of differences that are not real.

DM and OM digestibility from all treatments showed significantly different results. This happens because both the concentrate and the tofu waste are the types of animal feed that have high digestibility. The addition of tofu pulp at the same concentrate has the same crude fiber content so that it affects the digestibility of the same feed.

\section{Conclusion}

The conclusion from the study of the addition of tofu pulp in the concentrate is that it significantly affects the dry matter content and crude protein content, but not significantly different from crude fiber. The addition of tofu waste to the concentrate did not affect the dry matter digestibility or the organic matter digestibility.

\section{References}

Astuti, M. 2007. Pengantar Ilmu Statistik untuk Peternakan dan Kesehatan Hewan. Cetakan Pertama. Binasti publisher. Bogor.

Duldjaman, M. (2004). Penggunaan ampas tahu untuk meningkatkan gizi pakan domba lokal. Media Peternakan Journal of Animal Science and Technology, 27(3)

Harris, L.E. 1970. Nutition Research Techniques for Domestic and Wild Animal Volume I. Utah State University.

Mathius, I. W., \& Sinurat, A. P. (2001). Pemanfaatan inkonvensional bahan untuk pakan ternak.Wartazoa, 11(2), 20-31.

Nuraini. 2009. Performa Broiler dengan Ransum Mengandung Campuran Ampas Sagu dan Ampas Tahu yang Difermentasi dengan Neurospora crassa. Media Peternakan 32 (3): 196-203.

Parakkasi, A. 1991. Ilmu Nutrisi dan Makanan Ternak Ruminansia. Universitas Indonesia. Jakarta.

Sadzali, Imam. 2010. Potensi Limbah Tahu Sebagai Biogas. Jurnal UI Untuk Bangsa Seri Kesehatan, Sains, dan Teknologi 1 (12) :62-69.

Santoso, U. 1986. Limbah Bahan Ransum Unggas Yang Rasional. PT. Bhratara Karya Aksara: Jakarta.

Suprapti, M. L. 2005. Pembuatan Tahu. Kanisius: Yogyakarta.

Tetty. 2006. Pemanfaatan Kulit Pisang dan Ampas Tahu Terhadap Kinerja Ayam Buras.http://balitnak.litbang.deptan.go.id/mod.php?mod=publisher\&op=viewarti cle\&artid=88. (diakses tanggal 1 September 2014). 
Tilley, J.M.A. and R.A. Terry. 1963. A two stage technique for the in vitro digestion of forage crops. J. British Grassl. Soc. 18 : 104-111.

Utomo, R. 2010. Modifikasi metode penetapan kecernaan in vitro bahan kering atau bahan organik. Buletin Sintesis. 14 (1) : $1-11$.

Witjaksono, T. 2005. Pengaruh Pemberian Ampas Tahu Terhadap Pertambahan Bobot Badan Kambing Kacang Betina Pada Masa Pertumbuhan Awal. Skripsi. Universitas Brawijaya Fakultas Paternakan: Malang. 